\section{Performance of 67 Native Midwestern U.S. Perennials in a Low-maintenance Landscape}

\author{
Andrew L. Thomas ${ }^{1}$ and \\ Denny Schrock ${ }^{2}$
}

ADDiTIONAL INDEX wORDs. wildflower, drought-tolerant, indigenous

Summary. Hundreds of perennial plant species native to the midwestern United States have potential as ornamentals, but information on how best to use such plants in the landscape remains scarce. Many horticulturists are looking for species that perform well under low-maintenance conditions and that also attract and benefit desirable fauna, such as butterflies and birds. While many of our native plants may fit into this category, not all such species will meet aesthetic criteria for home landscapes. Some native species respond to seasonal changes in temperature and rainfall by browning or going dormant. Others have very specific site requirements for moisture, soil, and humidity that may be difficult to meet in an urban landscape, or their size, growth habit, or other characteristics may make them aesthetically undesirable in the typical home landscape. This study evaluated the performance of 67 plant taxa native to the midwestern United States selected for their promising potential in a low-maintenance landscape situation.

$\mathrm{M}$ ost plant species native to the midwestern United States have generally been overlooked for landscape purposes while showy, exotic taxa have dominated. In their book Perennials for American Gardens, Clausen and Ekstrom (1989) describe over 400 genera and several

${ }^{1}$ University of Missouri-Columbia, Southwest Research Center, 14548 Highway H, Mt. Vernon, MO 65712 .

${ }^{2}$ Meredith Corp., Des Moines, IA 50309

We express our sincere appreciation to Mark Muller, Linda Parker, Richelle Harris, Scott Woodbury, Mervin Wallace, Harlan Hamernik, and George Yatskievych. thousand species and cultivars of ornamental perennials, but fewer than $5 \%$ of these are native to eastern or midwestern North America. This may be due in part to the fact that many native plants are too large for backyard gardens, or have been somehow associated with weediness. Some may be difficult to propagate, while many others are simply unknown. Other authors (Burrell, 1997; McCargo, 1996; Snyder, 1991; Ulrich, 1993; Weaner, 1996) have suggested native species for landscape use, but present no data to validate their opinions of the best plants to use, especially for various geologic and climatic regions. Little research has been published on specific traits or qualities of perennials native to the midwestern United States. A large listing of plants of various prairie communities published by Robinson and White (1987) gave descriptive characteristics of plants and adaptability to various soil types, but made no attempt to evaluate plant performance in the landscape. Schrock and Thomas (1998) published an extensive, preliminary evaluation of herbaceous perennials native to the midwestern United States, indicating that many taxa show excellent potential in a low-maintenance landscape situation. Other studies conducted in the U.S. Great Plains (Locklear, 1995; Vickerman and Locklear, 1995) reported on plants adapted to the drier sections of the region.

Within the last 10 years, the interest in using native plants for landscape purposes has increased tremendously, and nurseries are struggling to keep up with demand. Both urban and rural gardeners are gradually discovering the ornamental potential and benefits of their indigenous flora. Much more information is needed as this developing trend in landscape horticulture gains momentum and interest.

The majority of plants used in landscapes are selected and placed with the intent of providing an aesthetically pleasing experience in an attempt to improve the appearance of a home site or other location. Most of the time, in assessing a species' contribution to the landscape, plants are treated as individuals; so plant height, width, color, and durability are important features to consider. For herbaceous perennials, the progression of plant characteristics through the seasons can be important considerations. Seasonal bloom, foliage color variations, and plant architecture through winter months may all contribute to effectiveness of the species in the garden. The objectives of this study were to determine the year-round landscape potential of 67 selected perennials native to the midwestern United States, and to document their survival and performance under lowmaintenance landscape conditions in southwest Missouri. A variety of horticultural data, including size, shape, bloom period, season-long appearance, flower and fruit characteristics, fall color, and survival was collected over six growing seasons.

\section{Materials and methods}

The experiment was conducted from 1995 through 2001 at the University of Missouri-Columbia's Southwest Research Center located near Mt. Vernon in southwest Missouri at lat. $37^{\circ} 4^{\prime}$, long. $93^{\circ} 53^{\prime}$, and $1240 \mathrm{ft}(378.0 \mathrm{~m})$ altitude. The site is flat and exposed to full sun and strong southwesterly summer winds. The soil is a prairie-derived Hoberg silt loam (fine-loamy, siliceous, mesic Mollic Fragiudalf) that is moderately well-drained. During the study, annual rainfall ranged from 37.5 inches $(95.25$ $\mathrm{cm}$ ) in 2000 to 46.7 inches (118.62 $\mathrm{cm}$ ) in 1998, but the growing seasons of $1995,1998,1999,2000$, and 2001 were all considered droughty because of below-normal rainfall during the growing season. Maximum summer temperatures ranged from $95^{\circ} \mathrm{F}(35.0$ $\left.{ }^{\circ} \mathrm{C}\right)$ in 1997 to $106^{\circ} \mathrm{F}\left(41.1^{\circ} \mathrm{C}\right)$ in 2000, while minimum winter temperatures ranged from $-13^{\circ} \mathrm{F}\left(-25.0^{\circ} \mathrm{C}\right)$ in 1997 to $1^{\circ} \mathrm{F}\left(-17.2^{\circ} \mathrm{C}\right)$ in 1998.

The experiment was installed in two adjacent plantings. The first 30 taxa were obtained from Missouri Wildflowers Nursery (Jefferson City, Mo.) and planted on 23 May 1995. On 14 Apr. and 12-13 May 1997, an additional 40 taxa obtained from Shaw Nature Reserve (Gray Summit, Mo.) and Bluebird Nursery (Clarkson, Nebr.) were installed. While the majority of these selections were the unimproved wild species, a small number of named cultivar selections of native species were included. Three of the original taxa were later deleted from the study, leaving a total of 67 taxa (listed in "Taxon Names and Characteristics" section, below, and in Table 1). Water-permeable weed barrier fabric was anchored on top of the ground over the assigned 
Table 1. Characteristics and long-term survival of 60 native perennials in response to a low-maintenance setting at the University of Missouri's Southwest Center, Mt. Vernon, 1996-2001.

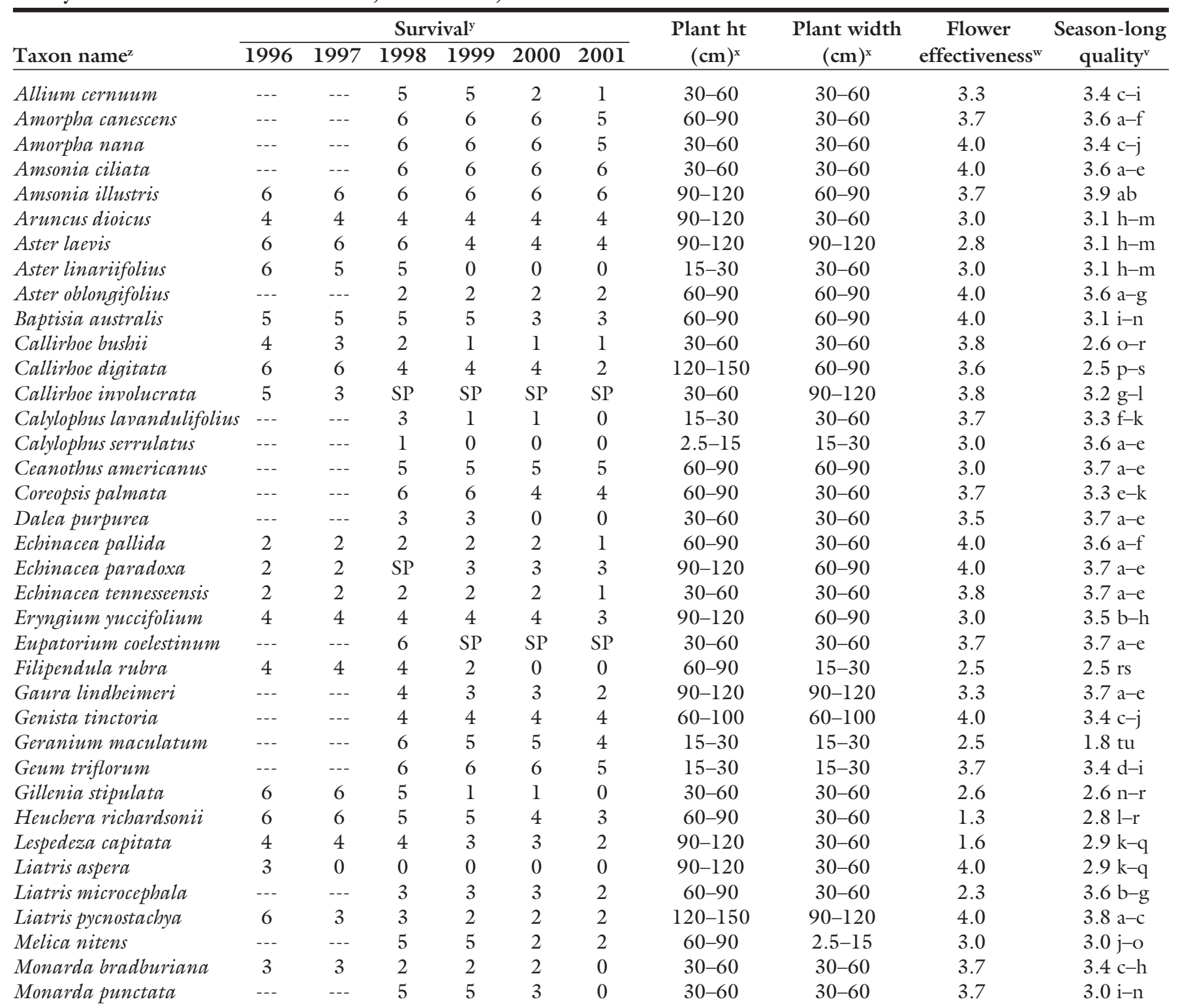

Table 1 continued on next page.

beds to suppress weed growth. Six container-grown plants per taxon were randomly assigned to single blocks within the trial area. Spacing between plants was determined by projected mature plant size. The young plants were transplanted through small holes cut into the weed barrier fabric, which was then covered with a thin layer of wood chips. Once the plants were well established, no supplemental irrigation was provided. Plants were never fertilized. Top growth of all plants remained in place until late winter, at which time it was cut back and removed. Otherwise, no pruning, shearing, or staking of plants occurred. Insect and disease problems were allowed to develop without intervention in order to evaluate each taxon's attractiveness and resistance to pests.

No data were recorded during the establishment year. In subsequent years, the following data were collected: at full bloom-plant height, plant width, plant growth habit, primary and secondary flower color, flower effectiveness, and flower coverage; at full fruit stage-fruit color, fruit effectiveness, foliage color, and foliage texture/type. Length of bloom, fruiting stages, and fall foliage color were also documented. Survival data were taken in late spring each season (1996-2001) after all surviving plants had had a chance to initiate growth. Ad- ditional positive and negative attributes were documented, such as fragrance, lodging, aggressiveness, attractiveness to desirable or beneficial fauna, insect pests, and diseases. A plant quality rating documenting the species' general attractiveness throughout the season was recorded every two weeks from April through October each year, with quality ratings based on a subjective scale of: $1=$ poor; 2 = fair; 3 = good; $4=$ excellent. These 10 to 12 seasonlong plant quality ratings per year over multiple years were averaged and compared among taxa using Duncan's multiple range test at a $P \leq 0.05$ level. Flower effectiveness was also based on the same scale $(1=$ poor, $\ldots 4=$ 


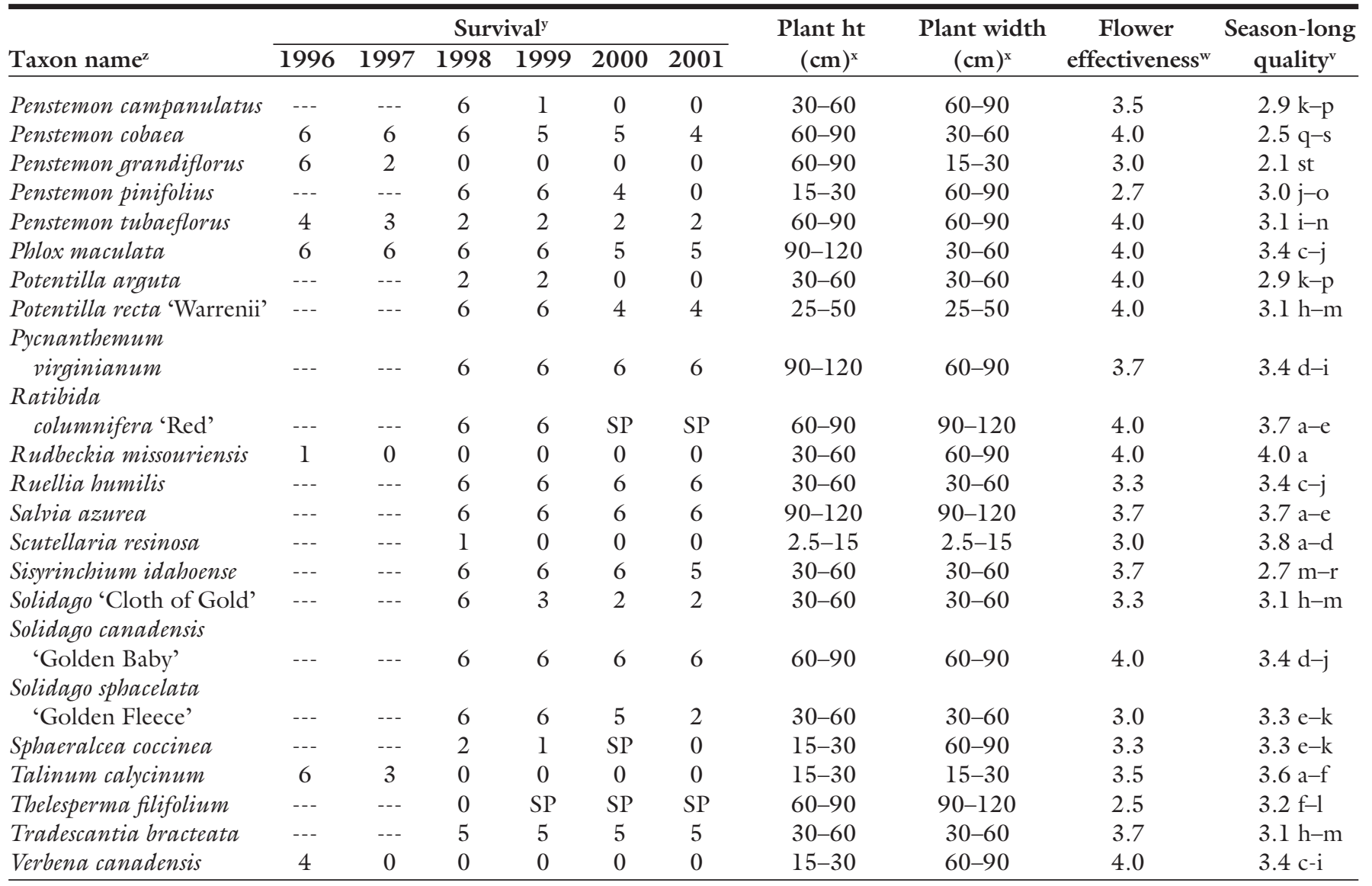

${ }^{2}$ Botanical synonyms and common names of taxa are detailed in text.

"Number of plants out of the original six individuals that survived; "SP" indicates plant is spreading or self-seeding.

${ }^{x} 1 \mathrm{~cm}=0.4$ inch.

"Means of ratings $(1=$ poor; 2 = fair; 3 good; $4=$ excellent $)$ recorded once at full bloom over multiple seasons.

${ }^{\mathrm{N}}$ Means of 10 to 12 annual temporal ratings $(1=$ poor; 2 = fair; $3=$ good; 4 = excellent $)$ combined over multiple seasons. Means within this column having different letters are significantly different $(P \leq 0.05)$.

excellent), but because those readings were taken only once per year (at full bloom), statistical comparisons were not made. Data and observations were recorded by different personnel each year to avoid bias.

\section{Results and discussion}

Many of the native plant taxa in this study exhibited good to excellent potential performance in a low-maintenance landscape situation, while some were consistently less attractive or possessed challenging characteristics that may require appropriate management if they are to be successfully used. Five of the 67 taxa [Penstemon albertinus, Penstemon whippleanus, Phlox pilosa, Senecio plattensis, and Silene virginica (Note: common names of all taxa are listed in "Taxon Names and Characteristics" section, below)] did not survive the initial planting season, indicating that either the propagation methods or the environment was not appropriate. No further data are presented on those five taxa. Two additional taxa (Liatris scariosa and Zizia aurea) survived the initial planting season but did not emerge the following year in good enough condition to provide quality data. Table 1 and Fig. 1, therefore, include data for 60 of the original 67 taxa. Survival data over 6 years are presented in Table 1 , along with plant height and width, flower effectiveness, and season-long quality. The statistical comparisons (Table 1 ) of seasonlong quality ratings among taxa help ascertain true differences in overall, year-to-year quality among the various taxa. A high season-long quality rating certainly indicates an outstanding and overall potentially useful plant. Examples of such promising taxa that also exhibited good survival include $A m o r-$ pha canescens, Amorpha nana, Amsonia ciliata, Amsonia illustris, Echinacea paradoxa, Echinacea tennesseensis, Eryngium yuccifolium, Eupatorium coelestinum, Phlox maculata, Ratibida columnifera 'Red', Ruellia humilis, and Salvia azurea. However, a lower season-long quality rating does not necessarily mean that a particular taxon in not garden-worthy. Some taxa may be stunning in full bloom but later become dormant, disorderly, or perhaps have unappealing infructescences. Such characteristics should not preclude a taxon's use in a low-maintenance native landscape setting, but rather point to the need for careful attention on its placement and use. Some of the most promising taxa in this category include Baptisia australis, Callirhoe involucrata, Coreopsis palmata, Geum triflorum, Penstemon cobaea, Potentilla recta 'Warrenii', Pycnanthemum virginianum, Sisyrinchium idahoense, and Solidago canadensis 'Golden Baby'. In Fig. 1, taxa are arranged in order of peak bloom from spring to fall, with date of peak bloom and bloom duration also presented. Such data can assist gardeners in selecting and combining various native taxa for season-long color and interest. 


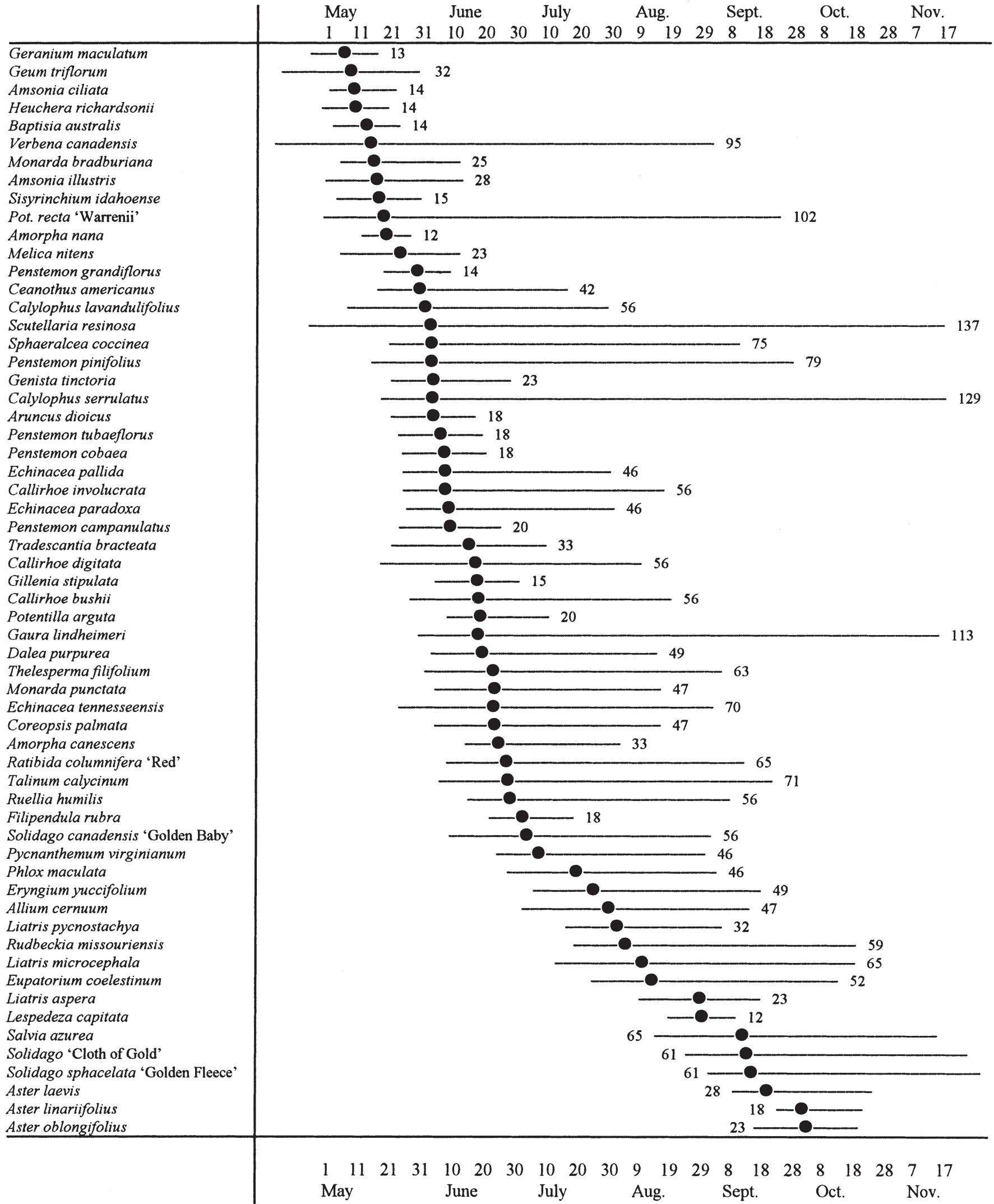

Fig. 1. Peak bloom ()$^{-}$and bloom duration $(-)$, with ordinal number of bloom days for 60 native plant taxa growing in a low-maintenance setting at the University of Missouri's Southwest Center, Mt. Vernon, averaged over all surviving seasons. 


\section{Taxon names and characteristics}

Following are the scientific and common names (Great Plains Flora Association, 1986; Steyermark, 1963; Yatskievych, 1999) of the 67 taxa included in the study. Synonyms, included in parentheses, are new and generally accepted name changes that are not yet well known. Following the name is a description of each taxon's performance in this study, detailing its flower color, attributes, and shortcomings, along with comments on using it in a landscape setting.

Allium cernumm, nodding wild onion: small plant with attractive pale pink flowers in midsummer; maintains nice foliage throughout summer with attractive fall regrowth.

Amorpha canescens, lead plant: excellent, tough, small woody shrub; attractive small grayish leaves and fruits with showy purple flowers; brief bloom period; drought tolerant.

Amorpha nana, dwarf false indigo: excellent, very small woody plant; compact form and shape; showy but small purple flowers; attractive fruits; drought tolerant.

Amsonia ciliata, fringed bluestar: beautiful, small plant; short-lived pale blue flowers in early spring; excellent shiny foliage retained nicely all summer; attractive golden yellow fall color; drought-tolerant.

Amsonia illustris, ozarks blue star: excellent, beautiful, tough plant; brief pale blue flowers in early spring; superb glossy foliage remains attractive all season; forms large sturdy non-woody "bush" with nice form; long thin seed pods add interest; attractive to aphids (Homoptera: Aphidae) and stink bugs (Hemiptera: Pentatomidae) but unharmed by them; excellent yellow fall color; drought tolerant.

Aruncus dioicus, goat's beard: nice, unique plant, but foliage is dull, purplish, and frequently mottled with leaf spots; attractive but short-lived cream flowers; fruiting stalk generally unattractive, brown; tolerates but turns brownish in drought; may perform better under partially shaded conditions as its natural habitat is often semi-shaded (Steyermark, 1963).

Aster laevis (Symphyotrichum laeve), smooth aster: plant is tall, disorderly, and somewhat weedy-looking; brief but welcome lavender bloom in early October; drought tolerant.
Asterlinariifolius (Ionactislinariifolius), stiff-leaf aster: small attractive plants; beautiful but brief composite bloom with blue ray and yellow disk flowers; very late bloom not bothered by frost; died out by fourth year.

Aster oblongifolius (Symphyotrichum oblongifolium), aromatic aster: attractive, small, compact plant; foliage is individually unattractive; brief spectacular lavender flowers in midOctober that attract a variety of colorful insects; fragrant foliage; drought tolerant.

Baptisia australis, blue wild indigo: plant habit is open and unique; stunning in bloom with profuse racemes of deep blue flowers; interesting large seed pods turn from green to black and persist; drought tolerant but plants often dry and turn black in late summer, going dormant or snapping off, but survive.

Callirhoe bushii, bush's poppy mallow: plants never thrived and generally appeared weak with little robust growth; foliage dull and often with brown areas or spots; some new foliage growth in early fall is attractive; showy magenta-purple flowers; appears to suffer or go dormant in drought; may perform better under partially shaded conditions as its natural habitat is often semi-shaded (Steyermark, 1963).

Callirhoe digitata, fringed poppy mallow: Tall, sparse plant with leaves only near base; often appears spindly because of lack of foliage; lodges easily; becomes unattractive in late summer often browning and going dormant; some attractive new basal growth in fall; stunning, delicate-looking magentapurple flowers; spent flower stalks could be cut back to improve appearance; best used in masses or scattered among other supporting species.

Callirboe involucrata, purple poppy mallow: stunning, vigorous, and tough plant that is highly recommended; ground cover often spreading 3 to $5 \mathrm{ft}(0.9-1.5 \mathrm{~m})$; excellent bright foliage through mid-summer; profuse numbers of bright magenta-purple flowers with long bloom period and sporadic re-bloom throughout much of summer; new plants appear sporadically but not aggressively; often becomes leggy and brownish in late summer when it could be cut back; attractive new foliage growth in fall.

Calylophus lavandulifolius, lavenderleaf sundrops: small, spreading, nicely-shaped plant with gray-green foliage; long sporadic yellow bloom throughout much of summer, flowers fade to orange; pinkish fall color with attractive fall foliage regrowth; wilts and dries in severe drought.

Calylophus serrulatus, yellow sundrops: small, compact plant with horizontal ground-cover form; showy bright yellow flowers with long bloom season; attractive to a variety of insects; nice plant but survival was not good.

Ceanothusamericanus, new jersey tea: excellent, small, highly-recommended woody shrub that is appealing all season long; attractive cream flowers yield pink, red, tan, and finally black fruits; nice small leaves persist late into fall; drought tolerant.

Coreopsis palmata, stiff tickseed, stiff coreopsis: Excellent plant with upright spreading form and medium size; bright yellow flowers in mid-June followed by attractive gray fruits that turn black and persist well into fall; fine bright foliage; occasionally lodges.

Dalea purpurea, purple prairie clover: attractive medium-sized plant with nice erect form; interesting bright purple flowers; delicate leaves and attractive grayish fruits; golden yellow fall color; perhaps short-lived as plants gradually died out.

Echinacea pallida, pale purple coneflower: beautiful, unique, and increasingly-familiar wildflower; pale purple recurved ray flowers and orange to brown disk flowers; attractive to bumblebees (Hymenoptera: Apoidea, Bombussp.) and butterflies (Lepidoptera); fruits attractive, fragrant, and persist into winter; drought tolerant but leaves sometimes become brown late in season.

Echinacea paradoxa, yellow coneflower: attractive, large, erect plant with tall, stately form; bold yellow flowers leaving behind large purplishbrown fruits (cones); drought tolerant but leaves may become brown late in season.

Echinacea tennesseensis (Echinacea pallida var. tennesseensis), tennessee coneflower: tough, long-lived plant; much shorter than other Echinacea, with ray flowers not recurved; beautiful soft pink-purple flowers with long bloom and continued sporadic bloom; drought tolerant but ray flowers and leaves may turn brown.

Eryngium yuccifolium, rattlesnake master: tall, coarse, and unique plant that appears spiny but is nevertheless handsome; individual flowers are white 
but rather indistinguishable within inflorescence; attractive to butterflies and other colorful insects; interesting fruits dry and turn brown, remaining intact and upright through winter; leaves occasionally turn brownish in late summer.

Eupatorium coelestinum (Conoclinium coelestinum), blue mist flower: beautiful plant with nice short form; unique delicate true blue flowers in late summer/early fall when little else is blooming; tends to seed around but not aggressively; re-seeds and may not be a long-lived perennial; emerges very late in spring; wilts in drought but survives and recovers nicely when rain returns.

Filipendula rubra, queen of the prairie: did not perform well in this study - plants grew poorly and foliage remained unattractive and brownish; flowers delicate pink, unique and stunning but few and not robust; fruit and infructescence unattractive; died out by fourth year; may perform better in a wetter site as the species naturally occurs in more moist areas (Steyermark, 1963).

Gaura lindheimeri, lindheimer's beeblossom: unique, beautiful, large plant with excellent form; small cream flowers with attractive pink to red bracts and reddish peduncles; long bloom period with sporadic re-bloom; plants performed well but gradually died out.

Genista tinctoria, dyer's greenweed: short, leafy, woody shrub with attractive small deep green foliage; form of plant is disorderly in appearance; short-lived yellow leguminous flowers; frequently defoliated by genista caterpillar (Lepidoptera: Pyralidae, Uresiphita reversalis) often leaving plant weak and unsightly. Not native but naturalized in North America (Bailey, 1949).

Geranium maculatum, wild geranium: small plant, individually coarse and unattractive with leaves that often turn yellow or brownish; beautiful delicate short-lived light purple flowers followed by interesting upright capsule fruits; probably better suited to light shade (Steyermark, 1963) but apparently drought and full-sun tolerant as it has persisted many years, sometimes going dormant in late summer.

Geum triflorum, prairie smoke: unique, very short, generally evergreen plant; tends to form a non-spreading groundcover; very early, spectacular, delicate, feathery, pinkish flowers with showy red bracts; fruits not evident but flowers dry, persist, and remain showy long after bloom; foliage deep green with a touch of red or purple throughout fall and winter; drought tolerant but may wilt or brown if severe; very persistent and long-lived in the study.

Gillenia stipulata (Porteranthus stipulatus), indian physic: generally nice but not outstanding plant; cream flowers individually attractive but overall not very effective; brief bloom period; infructescences brown and unattractive; leaves tend to brown throughout summer; early orange to red-brown to purple fall color; may perform better under partially shaded conditions as its natural habitat is often open woods (Steyermark, 1963).

Heuchera richardsonii, richardson's alum root: beautiful, compact, shiny-green rosette of leaves with excellent, mounded form; usually evergreen (reddish-green) through most winters; tall inflorescence with cream-colored flowers not particularly showy; fruits remain on tall brown stalks that are generally unattractive; could be used for excellent year-round foliage effect if dead infructescences are removed; attractive new foliage growth in early fall; drought tolerant but some leaf browning may occur.

Lespedeza capitata, roundheaded bush clover: nice, tall, somewhat spindly plant with slightly gray-green leaves; greenish-white flowers insignificant but fruits and bracts form an attractive brown "head" that persists well into winter; lodges frequently.

Liatris aspera, tall blazing star: attractive and unusual tall plant; interesting purple buds appear and swell over long period of time; welcome bright purple bloom in late summer; fruits start out pink, eventually forming gray-white fluffy achenes; attractive to butterflies and other insects; lodges occasionally; plants gradually died out.

Liatris microcephala, smallhead blazing star: excellent, short, colorful, unusual-looking plant with nice foliage spiraling up stems; showy purple late-summer bloom; drought tolerant but leaves may yellow.

Liatris pycnostachya, prairie blazing star: spectacular, large, unique, multiple-stemmed plant; tall spikes of bright purple flowers in late summer; attractive to butterflies and other insects; fruiting spikes interesting and persist well into winter.

Liatris scariosa, eastern blazing star: attractive pink-purple flowers followed by pink fruits turning brownish white with fluffy achenes; only one plant survived into second year, lodged, and did not recover.

Melica nitens, melic grass: short grass that generally did not perform well; individual plants are attractive pale green and delicate but not effective; nice short-lived pale green flowers but not showy; infructescence not persistent or showy; plants were never robust and gradually died out; might be used effectively in masses as it does not form a clump.

Monarda bradburiana, horsemint: excellent plant with nice, low, mounded form and deep purple-green glossy foliage; showy pink bracts appear before pink globe-shaped flowers; reddish fall foliage and gray fruits persist into winter; fragrant foliage and fruits; drought tolerant; persistent but gradually died out by sixth year.

Monarda punctata, spotted horsemint: interesting short plant with unusual green and white mottled leaves; persistent white bracts frame small light purple flowers; tends to become brown and dormant in drought but remains attractive with dried infructescences; fragrant foliage and fruits; attractive to butterflies and other insects; died out by fourth year.

Penstemon albertinus, alberta beardtongue: did not survive the initial season.

Penstemon campanulatus, bellflower beardtongue: beautiful, semievergreen plant; profuse striking bright purple flowers; often lodges forming unorganized but attractive mass of flowers; appeared to suffer in drought; survival not good and all plants had died by third year.

Penstemon cobaea, cobaea beardtongue: short multi-stemmed plant with glossy foliage; spectacular early spring bloom with masses of large blueish-purple flowers that attract bumblebees; drought tolerant but stems lodge and foliage generally turns brown and unattractive in late summer; fall regrowth of foliage is attractive; very persistent.

Penstemon grandiflorus, showy penstemon: multi-stemmed plant with glossy green foliage; attractive in bloom with light blue-lavender late spring flowers; purple-black fruit capsules shiny and attractive; consistently 
lodges after bloom; stems and foliage often turn brown and unattractive in late summer; nice early fall foliage regrowth; short-lived in this study and died out by third year.

Penstemon pinifolius, pineleaf beardtongue: small, stunning plant with unusual deep green narrow "pinelike" foliage that remains evergreen and attractive all winter; small tubular showy red flowers with long bloom period; tends to become brownish and unattractive in late summer; new green growth in fall; gradually died out.

Penstemon tubaeflorus, white wand beardtongue: multi-stemmed plant is attractive with glossy green foliage in spring; striking creamywhite flowers followed by showy shiny purple-black fruit capsules that persist well into winter; plant lodges severely in late summer becoming unattractive; drought tolerant but often browns in late summer; reddish bronze fall foliage color with new green growth; bestsurviving Penstemon in the study.

Penstemon whippleanus, whipple's beardtongue: did not survive the initial season.

Phlox maculata, meadow phlox: excellent, beautiful plant with nice, formal, erect form; spectacular pinkpurple flowers with long bloom period and sporadic re-bloom; occasionally turns brown and unattractive in drought, although apparently drought tolerant as long-term survival has been excellent.

Phloxpilosa, downy phlox: did not survive the initial season.

Potentilla arguta, tall cinquefoil: interesting, tall, rather coarse plant with large dull leaves; attractive creamy yellow-white flowers followed by unique brownish fruits; survival not good and all plants perished third year.

Potentilla recta 'Warrenii', sulphur cinquefoil: showy small plant with excellent form; masses of bright yellow flowers that persist and re-bloom over several weeks, often blooming again in late September; seed pods abundant and interesting; some new green foliage growth in fall; apparently drought tolerant but foliage often turns brownish in late summer while remaining attractive with dried seed pods. Native to Europe but naturalized and common throughout the midwestern U.S. (Steyermark, 1963).

Pycnanthemum virginianum, virginia mountain mint: nice, sturdy, longlived plant with excellent gray-green foliage; creamy-white flowers attractive to bumblebees and butterflies; foliage and fruits slightly fragrant; dried gray infructescences attractive and persist through winter; drought tolerant but may brown in late summer.

Ratibida columnifera 'Red', mexican hat: superb, tough plant that blooms nearly all summer; spreads around but not weedy; interesting multi-colored red to orange to yellow cone-type composite flowers produced profusely; grayish fruits attractive; may lodge but does not usually detract from appearance because plants grow together into masses; drought tolerant.

Rudbeckia missouriensis, missouri coneflower: attractive, dainty, yellow cone-type composite flower with long bloom season; did not survive into the second season.

Ruellia humilis, fringeleaf wild petunia: nice, tough, short, resilient plant; small blue-lavender flowers and dark fruits are individually attractive but not particularly effective overall; long bloom period; tends to seed around but is not weedy; drought tolerant but may brown in late summer.

Salvia azurea, azure blue sage: large, sometimes disorderly plant; spectacular, profuse deep blue flowers persist over long period in fall when little else is blooming; nice graygreen foliage; attractive to migrating monarch butterflies (Lepidoptera: Danaidae, Danaus plexippus) and other insects; few fruits are produced or are insignificant; drought tolerant but may wilt in extreme heat; excellent long-term survival.

Scutellaria resinosa, sticky skullcap: attractive small plant with unique purplish flowers nearly all summer long; did not survive into the second season.

Senecio plattensis, prairie ragwort: did not survive the initial season.

Silene virginica, fire pink: did not survive the initial season.

Sisyrinchium idaboense, idaho blue-eyed grass: small, attractive, and useful plant with deep green grass-like foliage; spectacular dark purple flowers with deep yellow centers are small but effective up-close; could be used effectively as groundcover or in masses; very persistent.

Solidago 'Cloth of Gold', cloth of gold goldenrod: plant is generally compact and attractive but consistently produced brown and dying individual branches from crown that lodged; beautiful yellow flowers in early fall followed by attractive golden brown infructescences; overall poor survival.

Solidago canadensis 'Golden Baby', golden baby canada goldenrod: tough, reliable, short, multi-stemmed plant; large pale yellow inflorescences topping every branch; flowers unevenly in mid-summer; gray infructescences attractive and persistent; leaves remain green well into winter; drought tolerant and long-lived; nicest of our three Solidagos.

Solidago sphacelata 'Golden Fleece', golden fleece autumn goldenrod: attractive short plant with rosette-like basal leaves surrounding stiff flowering shoots; many plants produce individually brown and dying branches from crown; uneven growth among plants; nice yellow flowers in fall that persist and rebloom over several weeks; brown infructescences abundant and interesting; some new green foliage growth in fall; apparently drought tolerant but tends to brown sometimes in late summer while remaining attractive with dried infructescences.

Sphaeralcea coccinea, scarlet globemallow: superb, small plant with low spreading habit and attractive pale green leaves; small bright rose-pink to red-orange flowers sporadically nearly all summer and well into late fall; foliage remains attractive and green until winter; drought tolerant; did not establish well and eventually died out.

Talinum calycinum (Phemeranthus calycinus), rock pink: attractive tiny succulent plant; spectacular pinkpurple flowers that open on sunny days; long bloom period; plant short-lived in this study and re-seeded for first 2 years before dying out completely; probably needs an even drier site as it naturally occurs on very hot dry glades with thin, rocky soils (Steyermark, 1963).

Thelesperma filifolium, stiff greenthread: spectacular, delicate, fineleaved, fairly large plant with excellent form; sporadic bright yellow flowers throughout much of summer and through October; small brown fruits following flowers interesting but shortlived; plant appears to behave as winter annual and easily re-seeds itself-germinating the following late summer; no plants survived first winter but became fully re-established by spring of third year and subsequently.

Tradescantia bracteata, longbract spiderwort: beautiful plant in spring and fall, but often becomes brownish, 
unattractive, and semi-dormant in late summer; beautiful violet flowers with yellow stamens in early summer generally open only in mornings; excellent green fall regrowth of foliage; excellent survival.

Verbena canadensis (Glandularia canadensis), rose verbena: beautiful, short, somewhat aggressively-spreading ground cover; long, sporadic bloom of showy purple flowers beginning in early spring; did not survive into second year.

Zizia aurea, golden alexanders: attractive small spring-blooming plant with abundant yellow flowers followed by interesting brownish umbels; did not survive into second year.

\section{Literature cited}

Bailey, L.H. 1949. Manual of cultivated plants. Macmillan Publ., New York.

Burrell, C.C. 1997. A heartland composition. Amer. Nurseryman 185(5):38-49.

Clausen, R.R. and N.H. Ekstrom. 1989. Perennials for American gardens. Random House, New York.

Great Plains Flora Association. 1986. Flora of the Great Plains. Univ. Press of Kansas. Lawrence.

Locklear, J.H. 1995. Great plants of the Great Plains. Horticulture 73(2):56-60.

McCargo, H. 1996. Natural selection. Amer. Nurseryman 184(4):39-45.

Robinson, R.T. and D.B. White. 1987. Prairie communities. AG-FO-3238. Minnesota Ext. Serv., Univ. of Minnesota, St. Paul.

Schrock, D. and A. Thomas. 1998. Native midwestern herbaceous perennials for landscape use. Univ. of Missouri-Columbia, Southwest Res. Ctr. Annu. Rpt., Mt. Vernon, Mo.

Snyder, L.C. 1991. Native plants for northern gardens. Andersen Hort. Library, Univ. of Minnesota, St. Paul.

Steyermark, Julian A. 1963. Flora of Missouri. Iowa State Univ. Press, Ames.

Ulrich, C. 1993. Prairie fire. Horticulture 71(11):52-57.

Vickerman, L.G. and J.H. Locklear. 1995. Wildflowers of the mixed-grass prairie. Amer. Nurseryman 182(9):28-35.

Weaner, L. 1996. New directions in the American landscape. Amer. Nurseryman 183(1):35-41.

Yatskievych, G. 1999. Steyermark's flora of Missouri, Rev. Ed., Vol. 1. Missouri Botanical Garden Press. St. Louis. 